\title{
A Review of Clinical Outcomes Associated with Two Meropenem Dosing Strategies
}

\author{
Kyle John Wilby ${ }^{1} \cdot{\text { Ziad Ghantous } \mathrm{Nasr}^{1} \cdot \text { Shereen Elazzazy }^{2} \cdot \text { Tim T. Y. Lau }}^{3}$ • \\ Anas Hamad ${ }^{2}$
}

Published online: 18 January 2017

(c) The Author(s) 2017. This article is published with open access at Springerlink.com

\begin{abstract}
Meropenem is a carbapenem antibiotic that exhibits time-dependent bactericidal activity, traditionally dosed intravenously at $1 \mathrm{~g}$ every $8 \mathrm{~h}$. In order to maximize its pharmacodynamic activity and reduce costs, an alternative regimen employed by many institutions is $500 \mathrm{mg}$ every $6 \mathrm{~h}$. The objective of this review was to summarize and evaluate published literature comparing clinical outcomes associated with these two meropenem dosing regimens. The literature was searched up to October 2016 using the MEDLINE, EMBASE, and Google Scholar databases. Three retrospective cohort studies were identified that compared clinical outcomes in general infectious disease patients (two studies) and patients with febrile neutropenia (one study). All studies reported no difference in clinical outcomes (clinical success, time to defervescence, sign or symptom resolution, length of stay, mortality, need for other antibiotics, and seizure rates). One study reported reduced economic costs with the alternative dosing. Interpretation of findings was primarily limited by small sample sizes and generalizability. Based on the data reviewed, the alternative dosing regimen of meropenem $500 \mathrm{mg}$ intravenously every $6 \mathrm{~h}$ could be considered a therapeutic option. Future studies are needed to confirm the
\end{abstract}

Kyle John Wilby

kjw@qu.edu.qa

1 College of Pharmacy, Qatar University, PO Box 2713, Doha, Qatar

2 Pharmacy Department, National Center for Cancer Care and Research, Hamad Medical Corporation, PO Box 3050, Doha, Qatar

3 Pharmaceutical Sciences, Vancouver General Hospital, 899 W 12th Ave, Vancouver, BC V5Z 1M9, Canada findings of this review, especially in high-risk populations such as immunocompromised patients or those with severe infections.

\section{Key Points}

Meropenem dosing of $500 \mathrm{mg}$ every $6 \mathrm{~h}$ did not differ in clinical outcomes with a dosing strategy of $1 \mathrm{~g}$ every $8 \mathrm{~h}$.

The alternative dosing strategy may result in institutional cost savings due to lower drug acquisition costs.

\section{Introduction}

Appropriate use of antibiotics is a major target for health systems worldwide [1]. It is well known that antimicrobial overuse can contribute to poor patient outcomes, through promotion of antibiotic resistance, increased adverse events, and prolonged length of hospital stay [2]. These considerations can be detrimental to patients, as fewer agents are being developed to combat resistant infections [3]. Additionally, antibiotic-associated resistance is a major expenditure for institutions and is resulting in a heavy global economic burden [4]. The clinical, epidemiological, and economic burdens of antibiotic overuse must be addressed to preserve the effectiveness of drug therapy and sustainability of health systems. Aside from antimicrobial stewardship, other strategies can be employed to improve 
the use of antibiotics and minimize associated costs. Optimization of dosing strategies, route of administration, and duration of therapy are considerations that can decrease overuse and wastage of targeted agents [5].

Meropenem, a carbapenem antibiotic that exhibits broad-spectrum activity, is an agent that has sparked clinical controversy regarding the most appropriate dosing strategy [6]. Traditionally, intravenous meropenem is dosed at $1000 \mathrm{mg}$ given every $8 \mathrm{~h}$. Alternative regimens have been studied in pre-clinical and pharmacokinetic studies, in order to determine equivalence through pharmacokinetic and pharmacodynamic perspectives [7]. For meropenem, its bactericidal activity is unrelated to plasma concentrations, but is instead dependent on the percentage of time the plasma concentrations are maintained above the minimum inhibitory concentration of the pathogen (\% $\mathrm{T}>\mathrm{MIC})$ [8]. Therefore, theoretically, lower doses given at more frequent intervals would optimize its killing activity. More specifically, a dose of $500 \mathrm{mg}$ given every $6 \mathrm{~h}$ is purported to demonstrate the same $\% \mathrm{~T}>\mathrm{MIC}$ to the traditional dosing regimen of $1000 \mathrm{mg}$ every $8 \mathrm{~h}$, and therefore is speculated to provide similar clinical effects. Although studies have assessed this alternative dosing strategy through a pharmacokinetic-pharmacodynamic perspective, clinical outcomes and comparison data between these different dosing regimens are lacking [9-11]. However, studies do suggest that this alternative dosing strategy will likely result in adequate pharmacodynamic endpoints to treat most non-severe infections.

Even though previous reviews have attempted to provide a better understanding of meropenem dosing strategies $[6,8]$, no review has been published that comprehensively compares the two dosing regimens mentioned above from an evidence-based clinical perspective. Therefore, the objective of this review is to evaluate and summarize the published literature comparing the clinical outcomes between administration of intravenous meropenem dosed at $1000 \mathrm{mg}$ every $8 \mathrm{~h}$ and $500 \mathrm{mg}$ every $6 \mathrm{~h}$.

\section{Methods}

A search of MEDLINE (1948-October 2016), EMBASE (1980-October 2016), and Google Scholar was conducted using combinations of the following search terms: "meropenem" or "carbapenem" with "dosage," "pharmacodynamics," and "clinical outcomes." The search was limited to English-language studies in human subjects. Articles were included in the review if they compared traditional (1000 mg every $8 \mathrm{~h}$ ) dosing with alternative (500 mg every $6 \mathrm{~h}$ ) dosing. Appropriately adjusted dosing for each regimen was allowed for compromised renal function if patients were analyzed as a whole. Articles were excluded if they were solely in patients with compromised renal function or in those receiving renal replacement therapy, or if no clinical outcomes were described. Clinical outcomes were defined as any outcome measure relating to efficacy or safety of drug therapy, including clinical success, mortality, length of hospital stay, duration of therapy, time to resolution of symptoms, or adverse events. Two investigators independently completed the literature search and assessed articles for inclusion. Discrepancies were resolved through discussion and consensus. Data were extracted as reported from the studies, and no further statistical analyses were performed. The quality of articles was assessed using the Critical Appraisal Skills Programme (CASP) Cohort Study Checklist [12].

\section{Results}

A total of 1107 articles were identified. Thirty-two articles remained after title and abstract screening. After full-text review, three articles met the inclusion criteria [13-15]. Reasons for exclusion of other articles were lack of reporting of clinical outcomes or composition of study population with all renal insufficient patients. All included studies were retrospective and single-centered, and are summarized in Table 1 . Table 2 provides the overall results of each study, and the quality analysis is displayed in Table 3. More detailed study evaluations are provided below.

Arnold et al. [13] conducted a retrospective cohort study to evaluate the use of imipenem-cilastatin $500 \mathrm{mg}$ every $6 \mathrm{~h}$, meropenem $1000 \mathrm{mg}$ every $8 \mathrm{~h}$, and meropenem $500 \mathrm{mg}$ every $6 \mathrm{~h}$ in adult febrile neutropenic patients with intolerances to or failure on cefepime after at least 3 days of therapy [13]. Data were collected over a 2-year period (September 1, 2005 to August 31, 2007), and 127 patients were identified that met inclusion criteria (Table 1). Of these patients, 40 received imipenem-cilastatin, 29 received traditional meropenem dosing (1000 mg every $8 \mathrm{~h})$, and 58 received alternative meropenem dosing (500 mg every $6 \mathrm{~h}$ ). A total of $76 \%$ of all patients received concurrent vancomycin, and there was a statistically significant $(p=0.04)$ difference in empiric antifungal use between the imipenem-cilastatin, traditional meropenem, and alternative meropenem groups (40, 76, and 64\%, respectively).

Results of this study are presented in Table 2. No differences were found in the primary outcomes of time to defervescence, need for additional antibiotics, or time to addition of first antibiotic. Secondary outcomes were also not significant with regards to duration of treatment, mortality, and seizure activity; all being similar or the same between all groups. The authors concluded that the study 
Table 1 Description of studies assessing meropenem dosing regimens of $1 \mathrm{~g} \mathrm{q} 8 \mathrm{~h}$ and $500 \mathrm{mg}$ q6h

\begin{tabular}{|c|c|c|c|c|c|c|}
\hline Study & Year & Objective & Design & Population & Exclusion & $\begin{array}{l}\text { Comparator } \\
\text { groups }\end{array}$ \\
\hline $\begin{array}{l}\text { Arnold } \\
\text { et al. } \\
{[13]}\end{array}$ & 2009 & $\begin{array}{l}\text { To compare clinical } \\
\text { outcomes between } \\
\text { neutropenic fever } \\
\text { patients treated with } \\
\text { imipenem } 500 \mathrm{mg} \mathrm{q} 6 \mathrm{~h} \text {, } \\
\text { meropenem } 1 \mathrm{~g} \mathrm{q} 8 \mathrm{~h} \text {, or } \\
\text { meropenem } 500 \mathrm{mg} \mathrm{q} 6 \mathrm{~h} \\
\text { following failure or } \\
\text { intolerance to cefepime }\end{array}$ & $\begin{array}{l}\text { Retrospective, } \\
\text { single-center, } \\
\text { observational } \\
\text { cohort }\end{array}$ & $\begin{array}{l}\text { Adults ( }>18 \text { years) with } \\
\text { hematological } \\
\text { malignancy and } \\
\text { neutropenic fever failing } \\
\text { or intolerant to cefepime } \\
\text { therapy; minimum } 3 \text { days } \\
\text { carbapenem therapy }\end{array}$ & $\begin{array}{l}\text { Received cefepime for } \\
<3 \text { days prior to } \\
\text { carbapenem initiation or } \\
\text { received inappropriate } \\
\text { carbapenem dose for } \\
\text { renal function for }>24 \mathrm{~h}\end{array}$ & $\begin{array}{l}\text { Imipenem- } \\
\text { cilastatin IV } \\
500 \mathrm{mg} \text { q6h } \\
\text { Meropenem IV } \\
1 \mathrm{~g} \mathrm{q} 8 \mathrm{~h} \\
\text { Meropenem IV } \\
500 \mathrm{mg} \mathrm{q6h}\end{array}$ \\
\hline $\begin{array}{l}\text { Patel } \\
\text { et al. } \\
{[14]}\end{array}$ & 2007 & $\begin{array}{l}\text { To compare outcomes and } \\
\text { cost for the traditional } \\
\text { US FDA-approved } \\
\text { dosing regimen for } \\
\text { meropenem vs. an } \\
\text { alternative dosing } \\
\text { regimen providing } \\
\text { similar } \\
\text { pharmacodynamic } \\
\text { exposure with a lower } \\
\text { total daily dose }\end{array}$ & $\begin{array}{l}\text { Retrospective, } \\
\text { single-center, } \\
\text { observational } \\
\text { cohort }\end{array}$ & $\begin{array}{l}\text { Historical controls: } \\
\text { patients receiving } \\
\text { meropenem } 1 \mathrm{~g} \mathrm{q} 8 \mathrm{~h} \text { or } \\
\text { q12h between Jan } 1 \text { and } \\
\text { Sep } 30,2004 \\
\text { Alternative dosing: } \\
\text { patients receiving } \\
\text { meropenem } 500 \mathrm{mg} \text { q6h } \\
\text { or q8h between Oct } 1 \text {, } \\
2004 \text { and Sep 30, } 2005\end{array}$ & $\begin{array}{l}\text { Patients }<18 \text { years old; } \\
\text { pregnancy; neutropenia, } \\
\text { meningitis; cystic } \\
\text { fibrosis; } \mathrm{CrCl}<25 \mathrm{~mL} / \\
\text { min; doses }>1 \mathrm{~g} \mathrm{q} 8 \mathrm{~h} \text { or } \\
<1 \mathrm{~g} \mathrm{q} 12 \mathrm{~h} \text {; if alternative } \\
\text { patients received }>1 \text { dose } \\
\text { of } 1 \mathrm{~g}, \text { patients converted } \\
\text { to traditional dosing; } \\
\text { patients receiving } \\
\text { inappropriate dose for } \\
\text { renal function }>1 \text { day; } \\
\text { patients with initial } \\
\text { organism resistant to } \\
\text { meropenem }\end{array}$ & $\begin{array}{l}\text { Meropenem IV } \\
1 \mathrm{~g} \mathrm{q} 8 \mathrm{~h}(\mathrm{CrCl} \\
>50 \mathrm{~mL} / \mathrm{min}) \\
\text { or } 1 \mathrm{~g} \mathrm{q} 12 \mathrm{~h} \\
(\mathrm{CrCl} \\
25-49 \mathrm{~mL} / \\
\mathrm{min}) \\
\text { Meropenem IV } \\
500 \mathrm{mg} \mathrm{q6h} \\
(\mathrm{CrCl} \\
>50 \mathrm{~mL} / \mathrm{min}) \\
\text { or } 500 \mathrm{mg} \mathrm{q} 8 \mathrm{~h} \\
(\mathrm{CrCl} \\
25-49 \mathrm{~mL} / \\
\mathrm{min})\end{array}$ \\
\hline $\begin{array}{l}\text { Kotapati } \\
\text { et al. } \\
{[15]}\end{array}$ & 2004 & $\begin{array}{l}\text { To compare the clinical } \\
\text { and economic outcomes } \\
\text { of administering } \\
\text { meropenem } 500 \mathrm{mg} \mathrm{q} 6 \mathrm{~h} \\
\text { vs. } 1000 \mathrm{mg} \mathrm{q} 8 \mathrm{~h}\end{array}$ & $\begin{array}{l}\text { Retrospective, } \\
\text { single-center, } \\
\text { observational } \\
\text { cohort }\end{array}$ & $\begin{array}{l}\text { All patients receiving at } \\
\text { least one dose of } \\
\text { meropenem (Jan 2002- } \\
\text { Dec 2002) }\end{array}$ & $\begin{array}{l}\text { Received more than } 1 \text { day } \\
\text { of antibiotics previously } \\
\text { (unless unresponsive to } \\
\text { that therapy); received } \\
\text { higher dose than } \\
1000 \mathrm{mg} \text { q } 8 \mathrm{~h} \text { or } 500 \mathrm{mg} \\
\text { q6h; isolated organism } \\
\text { resistant to meropenem at } \\
\text { initiation; if } \mathrm{CrCl} \\
<25 \mathrm{~mL} / \mathrm{min} \text {; previous } \\
\text { hospitalization treated } \\
\text { with meropenem for } \\
\text { same indication }\end{array}$ & $\begin{array}{l}\text { Meropenem IV } \\
1 \mathrm{~g} \mathrm{q} 8 \mathrm{~h} \\
\text { Meropenem IV } \\
500 \mathrm{mg} \mathrm{q} 6 \mathrm{~h}\end{array}$ \\
\hline
\end{tabular}

$\mathrm{CrCl}$ creatinine clearance, $\mathrm{FDA}$ Food and Drug Administration, $I V$ intravenous, $q 6 h$ every $6 \mathrm{~h}, q 8 h$ every $8 \mathrm{~h}, q 12 \mathrm{~h}$ every $12 \mathrm{~h}$

did not provide any evidence that the alternative meropenem dosing strategy resulted in any adverse effects, but safety and efficacy of the regimen could not be confirmed. Limitations included a small sample size, which may have resulted in insufficient power to detect differences in clinical outcomes, a highly specific patient population (use of cefepime prior to carbapenem), and the use of concurrent medications which may have confounded the results. Despite these limitations, this study did not provide any signal or hypothesis-generating data that counter the use of the alternative meropenem dosing strategy in febrile neutropenic patients failing treatment with cefepime.

Patel et al. [14] conducted a retrospective cohort study to determine if an alternative meropenem dosing strategy (500 $\mathrm{mg}$ every $6 \mathrm{~h}$ ) results in similar clinical outcomes to traditional dosing and whether this regimen is associated with any pharmacoeconomic impact [14]. Patient records for traditional dosing were obtained between January 1 and September 30, 2004. Traditional dosing was defined as $1000 \mathrm{mg}$ every 8 or $12 \mathrm{~h}$ (if creatinine clearance was 25-49 $\mathrm{mL} / \mathrm{min}$ ). Patient records for alternative dosing were obtained from October 1, 2004 and September 30, 2005, if they received $500 \mathrm{mg}$ every 6 or $8 \mathrm{~h}$ (if creatinine clearance was $25-49 \mathrm{~mL} / \mathrm{min}$ ). All infectious indications that required meropenem therapy were included aside from febrile neutropenia and cystic fibrosis. Other exclusion criteria are listed in Table 1. A total of 100 patients met the inclusion criteria for the traditional dosing arm, and 192 patients for the alternative dosing arm. Baseline characteristics were similar between groups, including use of 
Table 2 Results of studies assessing meropenem dosing regimens of $1 \mathrm{~g}$ every $8 \mathrm{~h}$ and $500 \mathrm{mg}$ every $6 \mathrm{~h}$

\begin{tabular}{|c|c|c|c|c|}
\hline Study & Outcome & $\begin{array}{l}\text { Meropenem } 500 \mathrm{mg} \\
\text { every } 6 \mathrm{~h}\end{array}$ & $\begin{array}{l}\text { Meropenem } 1 \mathrm{~g} \\
\text { every } 8 \mathrm{~h}\end{array}$ & Significance \\
\hline \multirow[t]{4}{*}{$\begin{array}{l}\text { Arnold et al. } \\
{[13]}\end{array}$} & Median time to defervescence (days) & $3(n=44)$ & $2(n=22)$ & $\begin{array}{l}\text { HR } 0.881,95 \% \text { CI } \\
0.511-1.519\end{array}$ \\
\hline & Need for additional antibiotics & $8 / 58$ patients $(13.8 \%)$ & $\begin{array}{l}5 / 29 \text { patients } \\
(17.2 \%)\end{array}$ & NS \\
\hline & $\begin{array}{l}\text { Median (range) time to addition of first antibiotic } \\
\text { (days) }\end{array}$ & $1(1-6)(n=58)$ & $2(1-22)(n=29)$ & $\begin{array}{l}\text { HR } 0.645,95 \% \text { CI } \\
\quad(0.208-1.998)\end{array}$ \\
\hline & Median (range) duration of treatment (days) & $8(3-35)(n=58)$ & $8(3-25)(n=29)$ & $\begin{array}{l}\text { HR } 1.124,95 \% \text { CI } \\
0.685-1.845\end{array}$ \\
\hline \multirow{4}{*}{$\begin{array}{l}\text { Patel et al. } \\
\text { [14] }\end{array}$} & In-hospital mortality & $11.5 \%(n=192)$ & $8 \%(n=100)$ & $p=0.238$ \\
\hline & $\begin{array}{l}\text { Median (range) meropenem-related length of } \\
\text { stay (days) }\end{array}$ & $9(1-67)(n=192)$ & $7(1-44)(n=100)$ & $p=0.141$ \\
\hline & Median (range) duration of therapy (days) & $4(1-27)(n=192)$ & $5(2-22)(n=100)$ & $p=0.055$ \\
\hline & Success rate & $92.1 \%(n=192)$ & $90.9 \%(n=100)$ & $p=0.72$ \\
\hline \multirow{6}{*}{$\begin{array}{l}\text { Kotapati et al. } \\
{[15]}\end{array}$} & Clinical success rate (evaluable patients) & $28 / 36(78 \%)$ & $32 / 39(82 \%)$ & $p=0.862$ \\
\hline & Clinical success rate (monotherapy) & $24 / 29(83 \%)$ & $17 / 21(81 \%)$ & $p=1.000$ \\
\hline & Microbiological success rate & $19 / 30(63 \%)$ & $19 / 24(79 \%)$ & $p=0.334$ \\
\hline & $\begin{array}{l}\text { Rate of response (days to normalization of } \\
\text { temperature) }\end{array}$ & $3(n=36)$ & $3(n=39)$ & $p=0.476$ \\
\hline & $\begin{array}{l}\text { Rate of response (days to normalization of } \\
\text { lymphocyte count) }\end{array}$ & $4(n=36)$ & $4.5(n=39)$ & $p=0.927$ \\
\hline & Meropenem-related length of stay (days) [IQR] & $7[4.8-13](n=45)$ & $7.5[4-10](n=40)$ & $p=0.891$ \\
\hline
\end{tabular}

$C I$ confidence interval, $H R$ hazard ratio, $I Q R$ interquartile range, $N S$ non-significant $(p>0.05)$

Table 3 Quality evaluation of identified studies according to the CASP-UK Cohort Study Checklist [12]

\begin{tabular}{|c|c|c|c|}
\hline Question & Arnold et al. [13] & Patel et al. [14] & Kotapati et al. [15] \\
\hline Did the study address a clearly focused issue? & Yes & Yes & Yes \\
\hline Did the authors use an appropriate method to answer their question? & Yes & Yes & Yes \\
\hline Was the cohort recruited in an acceptable way? & Yes & Yes & Yes \\
\hline Was the exposure accurately measured to minimize bias? & Yes & Yes & Yes \\
\hline Was the outcome accurately measured to minimize bias? & Can't tell & Can't tell & Yes \\
\hline Have the authors identified all important confounding factors? & Yes & Yes & Yes \\
\hline Was the follow-up of subjects complete enough? & Yes & Yes & Yes \\
\hline What are the results of this study? & Table 2 & Table 2 & Table 2 \\
\hline How precise are the results? & No & Can't tell & Can't tell \\
\hline Do you believe the results? & Can't tell & Can't tell & Can't tell \\
\hline Can the results be applied to the local population? & No & Can't tell & Can't tell \\
\hline Do the results of this study fit with other available evidence? & Yes & Yes & Yes \\
\hline
\end{tabular}

CASP Critical Appraisal Skills Programme

other concurrent medications and the source of infection. Intra-abdominal and respiratory infections were most commonly reported.

Results are given in Table 2. Clinical outcomes of meropenem-related length of hospital stay, in-hospital mortality, and duration of therapy did not significantly differ between the two arms. Overall clinical success (complete or partial resolution of leukocytosis, temperature, and clinical signs and symptoms of infection) rates were also similar, yet the median time to resolution of infection was shorter in the alternatively dosed patients $(n=156)$ versus the traditionally dosed ones $(n=87)(1.5$ vs. 3 days, $p<0.0001$, respectively). Pharmacoeconomic analyses demonstrated a decrease in drug acquisition costs with the alternative dosing strategy. Specifically, median cost per patient for the duration of therapy was US\$439.05 for traditional dosing and US\$234.08 for alternative dosing $(p<0.0001)$. The authors estimated that within the 1 year 
of data collection, a saving of approximately US $\$ 40,000$ occurred for the 192 patients treated. Limitations of the study include the small sample size and the single-centered design. In addition, a high percentage of concomitant antimicrobial therapy was observed in all patients $(56 \%$ traditional group vs. $66 \%$ alternative group). Despite these limitations, this study does not report evidence of harm using the alternative regimen, and the regimen may result in institutional cost savings.

Kotapati et al. [15] completed a retrospective cohort study to assess the clinical and economic outcomes associated with meropenem $1000 \mathrm{mg}$ every $8 \mathrm{~h}$ and $500 \mathrm{mg}$ every 6 h [15]. Study characteristics are given in Table 1. Patients were included if they received at least one dose of meropenem between January and December 2002. Patients were grouped according to the same traditional and alternative dosage groups as per Patel et al. [14], and were excluded if they previously received antibiotics, except in the case of antibiotic failure. Patients were included in the pharmacoeconomic analysis if they received 1 full day of meropenem and were considered clinically evaluable if they received at least 3 days. A total of 85 patients (40 traditional dosing and 45 alternative dosing) met the inclusion criteria for the pharmacoeconomic analysis, and 75 (39 traditional dosing and 36 alternative dosing) were clinically evaluable. Baseline characteristics were similar between groups. The most common site of infection was the lung.

Results are presented in Table 2. No difference in clinical outcomes was observed among groups. These included clinical success rate (acute or partial resolution of acute signs and symptoms of infection at end of meropenem therapy or discharge), microbiological success rate, response rate (days to normalization of temperature or lymphocyte count), and length of stay. Pharmacoeconomic analyses favored the alternative dosing regimen. Specifically, drug acquisition costs per patient were lower in the alternative dosing group compared with the traditional dosing group (US\$576 vs. US\$982, respectively, $p=0.009)$. Acquisition costs plus all costs associated with concomitant antibiotics and treatment of adverse effects per patient were also significantly reduced in the alternative dosing group compared with traditional dosing (US\$1035 vs. US\$1797, respectively, $p=0.008$ ). However, these costs in addition to meropenem-related length of stay costs were not significantly different between both groups (US\$19,934 vs. US\$16,087, respectively, $p=0.420$ ). The authors concluded that the two regimens were similar from a clinical perspective, but the alternative regimen was advantageous from an economic perspective. Limitations included the small sample size (i.e., lack of power to detect differences) and the lack of generalizability of economic data outside of the study center. Despite these limitations, this study did not provide any evidence of harm and suggested that drug acquisition costs are likely lower with the alternative dosing regimen.

\section{Discussion}

This paper examined the published literature reporting clinical outcomes associated with two meropenem dosing strategies. Three comparative studies were identified that did not demonstrate any significant differences in clinical outcome between traditional and alternative dosing [13-15]. It was shown, however, that alternative dosing may have economic advantages due to lower drug acquisition costs [14]. Despite identified limitations related to study design, small sample size, and lack of generalizability, the data presented in this review provide insight into an important question facing health institutions worldwide.

The consistent findings among the three studies were that meropenem $500 \mathrm{mg}$ every $6 \mathrm{~h}$ did not appear to have any differences in clinical outcomes, as compared to the $1 \mathrm{~g}$ every $8 \mathrm{~h}$ regimen. Although the small sample sizes likely lacked the power to detect meaningful differences between groups, the similar efficacy can be theoretically supported by meropenem's pharmacokinetic and pharmacodynamic profile [8]. As a time-dependent kill antibiotic, the more frequent dosing interval with the alternate dosing regimen (500 mg every $6 \mathrm{~h}$ ) would result in the same or higher percentage of time above the MIC as the traditional regime ( $1 \mathrm{~g}$ every $8 \mathrm{~h}$ ) [9]. Of course, any recommendations to implement alternative dosing must be done cautiously based on the limited evidence, especially for more severe infections.

A potential advantage of the alternative regimen could be the cost savings associated with drug acquisition [14]. Costs of meropenem likely differ worldwide, but the alternative dosing strategy results in a 2-g total daily dose, as compared to $3 \mathrm{~g}$ with traditional dosing. This difference of $33 \%$ may yield cost savings to health systems, especially in settings with high carbapenem utilization. If clinical outcomes are indeed deemed similar between dosing strategies, institutional switches to the alternative dosing strategy may reduce antimicrobial costs. Any savings, however, must be weighed against indirect costs such as increased workload regarding drug preparation by pharmacy staff and drug administration by nursing staff, and patient quality of life with the receipt of an extra dose per day. It should also be noted that the studies reporting economic outcomes were completed in 2004 and 2007 and drug acquisition costs have likely changed since this time. Therefore, any economic advantage must be studied at the institutional level. 
Findings must be interpreted in light of several limitations. The quality analysis identified a few methodological flaws, which should be noted. First, only three studies were identified, and each was limited by the retrospective nature of the study design. However, it is not likely that a prospective study would be conducted to address this particular question, and so this would become the best evidence available. Second, studies were limited by small sample sizes, which likely resulted in decreased power to detect differences between groups. Third, two studies included a broad range of infectious conditions, and thus it is not clear if the results obtained are applicable to a specific population $[14,15]$. On the other hand, one study specifically focused on febrile neutropenia patients who were intolerant to or failed on cefepime therapy and therefore lacks generalizability as a whole [13].

Despite the limitations mentioned, conclusions can be drawn from the data obtained. From a clinical perspective, there is no evidence to suggest that an alternative meropenem dosing strategy of $500 \mathrm{mg}$ every $6 \mathrm{~h}$ is inferior to traditional dosing of $1 \mathrm{~g}$ every $8 \mathrm{~h}$. The alternative strategy could therefore be considered as a potential therapeutic dosing regimen for patients requiring meropenem. Although strong evidence is lacking to support widespread changes to dosing guidelines, it is not likely that well-designed trials will be completed, because of resource limitations. Therefore, those already employing this practice should be encouraged to report long-term outcomes for both efficacy and safety. At the institution level, these clinical outcomes should be studied alongside economic outcomes, in order to determine overall benefits of alternative dosing.

In summary, there are limited data available that support the alternative dosing regimen of meropenem $500 \mathrm{mg}$ intravenously every $6 \mathrm{~h}$. Based on a clinical perspective and on pharmacokinetic/pharmacodynamics principles, this regimen appears to be safe and efficacious. Future studies are needed to confirm the findings of this review, especially in high-risk populations such as immunocompromised patients or those with severe infections.

\section{Acknowledgements None.}

\section{Compliance with Ethical Standards}

Conflicts of interest Dr. Kyle Wilby, Dr. Ziad Nasr, Dr. Shereen Elazzazy, Dr. Tim Lau, and Dr. Anas Hamad declare that they have no conflict of interest.

Funding No funding was provided for this review article.

Open Access This article is distributed under the terms of the Creative Commons Attribution-NonCommercial 4.0 International
License (http://creativecommons.org/licenses/by-nc/4.0/), which permits any noncommercial use, distribution, and reproduction in any medium, provided you give appropriate credit to the original author(s) and the source, provide a link to the Creative Commons license, and indicate if changes were made.

\section{References}

1. Lieberman JM. Appropriate antibiotic use and why it is important: the challenges of bacterial resistance. Pediatr Infect Dis J. 2003;22(12):1143-51.

2. Llor C, Bjerrum L. Antimicrobial resistance: risk associated with antibiotic overuse and initiatives to reduce the problem. Ther Adv Drug Saf. 2014;5(6):229-41.

3. Boucher HW, Talbot GH, Bradley JS, Edwards JE, Gilbert D, Rice LB, et al. Bad bugs, no drugs: no ESKAPE! An update from the Infectious Diseases Society of America. Clin Infect Dis. 2009;48(1):1-12.

4. Smith R, Coast J. The true cost of antimicrobial resistance. BMJ. 2013;346:f1493.

5. Leekha S, Terrell CL, Edson RS. General principles of antimicrobial therapy. Mayo Clin Proc. 2011;86(2):156-67.

6. Perrott J, Mabasa VH, Ensom MHH. Comparing outcomes of meropenem administration strategies based on pharmacokinetic and pharmacodynamic principles: a qualitative systematic review. Ann Pharmacother. 2010;44:557-64.

7. Mattoes HM, Kuti JL, Drusano GL, Nicolau DP. Optimizing antimicrobial pharmacodynamics: dosage strategies for meropenem. Clin Ther. 2004;26(8):1187-98.

8. Nicolau DP. Pharmacokinetic and pharmacodynamic properties of meropenem. Clin Infect Dis. 2008;47(Supplement 1):S32-40.

9. Cheatham SC, Kays MB, Smith DW, Wack MF, Sowinski KM. Steady-state pharmacokinetics and pharmacodynamics of meropenem in hospitalized patients. Pharmacotherapy. 2008;28(6):691-8.

10. Kuti JL, Florea NR, Nightingale CH, Nicolau DP. Pharmacodynamics of meropenem and imipenem against enterobacteriaceae, Acinetobacter baumannii, and Pseudomonas aeruginosa. Pharmacotherapy. 2004;24(1):8-15.

11. Kuti JL, Maglio D, Nightingale CH, Nicolau DP. Economic benefit of a meropenem dosage strategy based on pharmacodynamic concepts. Am J Helath Syst Pharm. 2003;60(6):565-8.

12. CASP Cohort Study Checklist. Critical Appraisal Skills Programme (CASP)-UK. 2013. http://www.casp-uk.net/casp-toolschecklists. Accessed 11 Oct 2016.

13. Arnold HM, McKinnon PS, Augustin KM, Hladnik LM, Casabar E, Reichley RM, et al. Assessment of imipenem-cilastatin 500 $\mathrm{mg}$ q6h, meropenem $1 \mathrm{~g} \mathrm{q} 8 \mathrm{~h}$ and meropenem $500 \mathrm{mg}$ q6h following cefepime use in adult patients with neutropenic fever. Pharmacotherapy. 2009;29(8):914-23.

14. Patel GW, Duquaine SM, McKinnon PS. Clinical outcomes and cost minimization with an alternative dosing regimen for meropenem in a community hospital. Pharmacotherapy. 2007;27(12):1637-43.

15. Kotapati S, Nicolau DP, Nightingale CH, Kuti JL. Clinical and economic benefits of a meropenem dosage strategy based on pharmacodynamic concepts. Am J Health Syst Pharm. 2004;61:1264-70. 